\title{
Better than a sackful of Latin: anticlericalism in the Middle Dutch Dit es de Frenesie (c.1325)
}

\author{
Ben Parsons - University of Leicester \\ Bas Jongenelen - Fontys University of Professional Education, Tilburg
}

\begin{abstract}
This article offers the first substantial survey of the Middle Dutch satire Dit es de Frenesie since the work of C.P. Serrure in the mid nineteenth century. It contests much of the conventional wisdom surrounding $D e$ Frenesie, such as the poem's usual classification as an early boerde or fabliau. Instead it is argued that the text is an experimental work, which blends together elements of several satiric traditions without committing itself to any one. The implications of this manoeuvre and others within the text are considered, revealing the poem's clear sympathy with the newly educated and articulate laity. De Frenesie itself is appended in both the original Middle Dutch and an English verse translation.
\end{abstract}

Among critics in the Low Countries, the brief satire Dit es de Frenesie ('This is the Madness') has usually attracted attention for one of two reasons. On the one hand, it has been singled out as the earliest example of the boerde, a Middle Dutch off-shoot of the French fabliau. In Cornelis Kruyskamp's authoritative edition of the boerden, De Frenesie is hailed as 'kostlijk en kostbaar' ('valuable and precious') for being the first extant witness to the form. ${ }^{1}$ The poem has also invited similar comments from Willy Braekman. ${ }^{2}$ On the other hand, the poem has received notice for the astonishing virulence of its anticlericalism. Jan te Winkel, for instance, describes the piece as 'merkwaardig om den hatelijken toon tegen dat paepscap' ('remarkable for its tone of animosity towards the papacy'), while P.H. Moerkerken states that in portraying clerics 'de dichter van het zonderlinge stukje Dit es de frenesie heeft er tenminste niet veel eerbied' ('the composer of the peculiar piece De Frenesie does not display the least respect'). ${ }^{3}$ It is the purpose of the present essay to examine the second of these features, and analyse the ways in which De Frenesie coordinates its attacks on the church. In particular, it will consider the wider currents of hostility it draws on in formulating its aggressive stance, and what its usage of this material can reveal.

De Frenesie has survived in one imperfect and unsigned copy which is datable to 1313-25 on the strength of its manuscript context. ${ }^{4}$ Its manuscript, the so-called 'Amsterdamsche handschrift', is now held at the Library of the Royal Academy of Sciences. This seems to have preserved a fragmentary version of the poem. Not only

\footnotetext{
${ }^{1}$ Cornelis Kruyskamp, De middelnederlandse boerden voor het eerst verzameld ('s-Gravenhage: M. Nijhoff, 1957), p.10.

${ }^{2}$ Medische en technische Middelnederlandse recepten. Een tweede bijdrage tot de geschiedenis van de vakliteratuur in de Nederlanden, ed. by Willy L. Braekman (Ghent: Koninklijke Vlaamse Academie voor Taal- en Letterkunde, 1975), pp.9-10.

${ }^{3}$ Jan te Winkel, De ontwikkelingsgang der Nederlandsche Letterkunde, 7 vols. (Haarlem: De erven F. Bohn, 1922-7), II (1922): Geschiedenis der Nederlandsche letterkunde van Middeleeuwen en Rederijkerstijd, p.20; P.H. Moerkerken, De satire in de Nederlandsche kunst der middeleeuwen (Amsterdam: S.L. van Looy, 1904), p.58.

${ }^{4}$ See Jan Willem Klein, "'Het getal zijner jaren is onnaspeurlijk". Een herijking van de dateringen van de handschriften en fragmenten met Middelnederlandse ridderepiek', Tijdschrift voor Nederlandse Taal- en Letterkunde 111 (1995), p.7.
} 
has damage all but deleted two lines of verse, but an unknown amount of text may be missing from the end. De Frenesie is the final item in the manuscript, and the last page of the codex is lost. The poem itself is anonymous, although there has been some speculation regarding its authorship. The nineteenth-century scholar C.P. Serrure suggested that it might be an early work of Heinric or Hein van Aken, thought to have composed a number of romances and courtesy books at the close of the thirteenth century. ${ }^{5}$ Serrure based his attribution on the fact that the Amsterdamsche handschrift also contains an early Dutch translation of the Roman de la Rose, known as Die Rose (c.1290), which is sometimes assigned to Van Aken: nonetheless, this evidence aside, Serrure admitted that the mainstay of his theory was little more than 'bloote gissing', or 'naked conjecture'. ${ }^{6}$ The attribution of Frenesie to Van Aken has never gained wide acceptance. It has even been ruled out specifically by W.J.A. Jonckbloet and Eelco Verwijs, who point out that De Frenesie's allusions to Coudenberge, Biesterveld and Kempen place the author in North Brabant, whereas Van Aken has stronger ties to Flanders or the Rhineland. ${ }^{7}$ The attribution is further complicated by the fact that Van Aken's authorship of Die Rose is itself insecure. ${ }^{8}$ It therefore seems unlikely that the composer of De Frenesie can be identified with any certainty.

The poem itself takes the form of a biecht or literary confession. ${ }^{9}$ It is delivered by a Dutch student at Paris while he is apparently in bed with a local prostitute. In the space of the poem's ninety-four surviving lines, the student relates the romantic misfortunes that drove him to school, his preference for pies and dice over books, and his difficulty in obtaining a profitable benefice. As the poem concludes he attempts congress with his bedfellow. Judging from the fruitlessness of this coupling, the girl and her client are equally inexperienced: 'ende legt mi ouer dander side/ Mi dunct altenen dat ic ride/ alse nv langes, alse nv dwers' ('She lies over on my other side: I think she means that I should ride first one way, and then the other').

Aside from these episodes, the poem's most striking feature is its satire against the church. The narrator weaves several complaints against ecclesiastic institutions into his speech. These are bitter and wide-ranging, inveighing against consistory courts, systems of preferment, the ignorance of secular clerics, and the futility of academic learning. These attacks reach perhaps their highest pitch in the ambiguous declaration 'paepscap es al loes' ('the papacy contains nothing', or 'the papacy is all void'). The very fact that no further explanation is given for this remark renders it all the more corrosive. A number of potential meanings are brought into play at once, as the poem does not specify whether its statement describes emptiness of virtue, wisdom, honesty, or even spiritual authority or divine sanction: instead, it gestures towards all of these possibilities at the same time, without limiting itself to one alone.

\footnotetext{
${ }^{5}$ See Hein van Aken, Van den coninc Saladijn ende van Hughen van Tabaryen, ed. by P. de Keyser (Leiden: Brill, 1950).

${ }^{6}$ C.P. Serrure, Vaderlandsch museum voor Nederduitsche letterkunde, oudheid en geschiedenis, 5 vols. (Ghent: H. Hoste, 1855-63), III (1861), p.59.

${ }^{7}$ W.J.A. Jonckbloet, Geschiedenis der Nederlandsche letterkunde, 2 vols. (Groningen: J.B. Wolters, 1889), II: De Middeleeuwen, p.219; Hein van Aken, Die Rose, ed. by Eelco Verwijs (Utrecht: H.E.S. Publishers, 1976), p.xxv.

${ }^{8}$ Dieuwke van der Poel, 'The Romance of the Rose and I: Narrative Perspective in the Roman de la Rose and its Two Middle Dutch Adaptations', in Courtly Literature: Culture and Context, ed. by Keith Busby and Erik Kooper (Amsterdam: John Benjamins, 1990), pp.573-85.

${ }^{9}$ J.W. Muller, 'Reinaert-studiën. III. Aernout en Willem. B. Het dubbel auteurschap van Reinaert I A en B', Tijdschrift voor Nederlandsche taal-en letterkunde 53 (1934), p.163.
} 
Furthermore, the context in which this charge is made renders it even more piquant. It in fact serves as a mock-apology for the shady practice of embroiling low-ranking clerics in expensive lawsuits. The author argues that the curia needs to be rapacious, needs to draw in revenue from poorer clerics, because it has no substance of its own:

Ic en behoude niet.

Dus es den menichgen gesciet

die sonder recht tsine verloes,

want dat paepscap es al loes.

(I must walk away poor.

It's happened to many men before.

They found they'd lost everything,

For the papacy contains nothing.)

The play of irony in these lines drives home an unmistakable point. Corruption in the church is emphatically presented as indefensible: even an attempt to rationalise current abuses only leads to further, more explosive charges being laid at the clergy's door. There is no secure ground on which ecclesiastic practices are based, as trying to find underlying validity only uncovers further layers of corruption. The poem, in short, is unequivocal in its condemnation of the 'paepscap', a hostility it extends to the church as a whole.

For a number of decades, it has been customary to regard the poem's derogatory treatment of the clergy as singular, even eccentric. The observations of Moerkerken and Te Winkel epitomise this tendency, as they respectively describe the poem as 'zonderlinge' ('peculiar') and 'merkwaardig' ('remarkable'). Nonetheless, such a view of the piece is misleading in many crucial respects. It would seem to imply that there is something exceptional, even unique, about the poem's satire, that it represents a marginal and individual set of criticisms. The opposite is in fact closer to the truth: although the poem is in some respects unusual, the antipathies it registers are in every case highly typical. Each of the complaints it makes against the priesthood can be traced to a specific tradition of medieval satire or complaint against the church. Its arguments are, in other words, largely derivative. While they are often used in interesting ways, their substance is in every case drawn from an existing corpus of tropes and accusations. However, what is unique in the poem is the convergence of these different strands of enmity, and of the different generic forms in which such enmity is usually expressed. Although the confluence of these discourses is sometimes uneasy, and at points generates friction in the text, the very fact that they have been gathered into a single work is itself notable. This tactic in itself has interesting implications, which will be discussed in due course.

Perhaps the most immediately obvious source of the poem's satire is the fabliau. Its classification as a boerde would already suggest some connection to this genre: many of the other boerden, such as Vanden vesscher van Parijs (late fifteenth century) or Ic prijs een wijf (c.1400), are translated directly from the fabliaux or related sources. ${ }^{10}$

\footnotetext{
${ }^{10}$ See Kruyskamp, De middelnederlandse boerden, pp.100-8, 80-3; Germaine Dempster, 'Some Old Dutch and Flemish Narratives and Their Relation to Analogues in the Decameron', Publications of the Modern Language Association of America 47 (1932), pp. 923-948; Karel Eykman, and Frederik
} 
De Frenesie certainly follows many of the contours of the French form. Even a cursory glance reveals sufficient references to 'scatology, scattered body parts and sexual explicitness' for the poem to qualify as a fabliau. ${ }^{11}$ From the opening reference to 'menichgen, als hi slaept,/ sijn ers herde wide gaept' ('many people, while they are sleeping, their arses are still widely gaping'), to its concluding episode of unsuccessful sexual acrobatics, the text seizes on the scandalous aspects of the fabliau with consistency and relish. Along similar lines, the very persona of its narrator seems to be imported from the fabliaux: his poverty and lechery recall the archetypal clers escoliers of La Borgoise d'Orliens or Des trois Avugles de Compiengne, to name but two examples. ${ }^{12}$ However, away from these fairly straightforward borrowings, the text also displays further traits of the genre. In particular, it shares the fabliau's antagonistic relationship with higher discourses, especially the romance. From the start De Frenesie systematically inverts many romantic conventions. Its narrator complains of love-sickness, bewailing that his love will 'mi steruen daede' ('kill me dead'), although the metaphors he selects to describe his suffering are markedly more mundane than elevated: at one point he laments 'ic worden...graeu als ene catte' ('I have become...as grey as a cat'), a simile that doubly undercuts his extravagant pining, suggesting homeliness on the one hand and animality on the other. ${ }^{13}$ Moreover, he also allows boredom or self-preservation to overcome the usual 'depression and self-abasement' induced by amor hereos. ${ }^{14} \mathrm{He}$ eventually leaves his mistress for the fleshpots of Paris, reflecting that 'want hine dult algader niet/ die te haluen wege weder tiet' ('it is not foolish in any way if one turns back after halfway'). Other high discourses are exposed to similar ridicule. The opening section of the text parodies the conventions typical of a rhetorical exordium, reading as a sort of distorted captatio benevolentiae. The narrator claims that he works all night on his compositions, provided that he is not asleep, before comparing his verse to the 'blaest' ('blasting') of nocturnal flatulence: his work is therefore less divine inspiration and more earthly exhalation. ${ }^{15}$ All of this clearly recalls the fabliaux, sharing in its commitment to 'invert the proprieties of official culture'. ${ }^{16}$

What is more, the poem itself registers some degree of French influence. Although it is unlikely that the poem simply follows a French source, since many of its jokes rely on the narrator's poor grasp of the language and would not be possible in a francophonic text, its very title suggests some French inspiration. The word 'frenesie' is itself French, and is not commonly used in Dutch. In fact, to this day some

Lodder, Van de man die graag dronk en andere Middelnederlandse komische verhalen (Amsterdam: Promotheus, 2002), pp.32-47.

${ }^{11}$ Jerry Root, 'The Old French Fabliau and the Poetics of Disfiguration', Medievalia Et Humanistica 24 (1997), p.17.

${ }^{12}$ Fabliaux et contes des and Dominique Martin Meon (Paris:

, ed. by Etienne Barbazan Baldwin, 'Chaucer, Medieval Drama and a Newly Discovered Seventeenth-Century Play: the survival of medieval stereotypes?', in Farce and Farcical Elements, ed. by Wim N. M. Hüsken and others (Amsterdam: Rodopi, 2002), p.89.

${ }^{13}$ On similar metaphors in the fabliaux, see Anne Elizabeth Cobby, Ambivalent Conventions: Formula and Parody in Old French (Amsterdam: Rodopi, 1995), p.70.

${ }^{14}$ Mary Wack, Lovesickness in the Middle Ages: The Viaticum and Its Commentaries (Philadelphia: University of Pennsylvania Press, 1990), p.162.

${ }^{15}$ Herman Pleij, 'Literatuur als medicijn in de late middeleeuwen', Literatuur 2 (1985), p.30.

${ }^{16}$ Lillian M. Bisson, Chaucer and the Late Medieval World (New York: St Martin's Press, 1998), p. 257 . 
commentators are obliged to render it as the more familiar waanzin. ${ }^{17}$ When this is added to the Parisian setting of the poem, and the incorporation of French phrases and idioms, it is clear that the piece demonstrates a firm connection to French comic literature.

Given the De Frenesie's proximity to the fabliaux, it is tempting to see its attacks against the church as a natural extension of this kinship. After all, hostility to priests is a staple part of the fabliau tradition. Since the work of George Staintsbury it has been noted that the form is committed to 'lampooning' the priesthood: such an observation is only reinforced by Daron Burrows' recent survey of the issue. ${ }^{18}$ In fact, a high proportion of extant fabliaux display a marked antipathy towards clerics. John Baldwin's examination of 50 fabliaux finds that no fewer than 23 contain scurrilous portrayals of the clergy. ${ }^{19}$ Ivan Fonagy produces some comparable data, finding that around 70 texts out of 152 depict the priesthood as lechers, schemers or hypocrites. ${ }^{20}$ This animosity was imported directly into the Dutch boerden. Willem van Hildegaersberch's Vanden monick (c.1400), and the anonymous Wisen raet van vrouwen (c.1399), feature lecherous and stupid clerics who are duly abused. Along similar lines, Een speel van drie minnen (c.1520), a text closely related to the thirteenth-century Constant du Hamel, features a central trick in which a 'pape' and 'coster', or priest and sexton, unknowlingly terrorise one another until their 'minds are overwhelmed'. ${ }^{21}$ There are at least some grounds, therefore, for linking De Frenesie's anticlericalism with its foundation in the fabliau.

However, such a conclusion is not without its problems. Although it is usually classified as a typical boerde, and even singled out as the the initiator of this tradition, the fact is that De Frenesie's relationship with the fabliaux is not merely one of simple imitation. While the piece has clear resemblances to the form, it does not completely or exclusively adhere to its parameters. In fact it demonstrates much the same difficulties as the handful of Middle English fabliau-texts, such as Dame Sirith and De Interludium Clerico ad Puella. Like them, it 'shows the fabliau in the process of becoming theatre', since it is structured more like a drama than a poetic text. ${ }^{22}$ Like the English pieces, it is clearly designed for dramatic performance: the fact that it has a clearly identifiable, explicitly characterised narrator requires that it be played rather than simply recited, and it incorporates one other brief speaking part, as the student's bedfellow interjects her own voice at one stage in the text. Consequently, it demonstrates the same features which move Keith Busby to brand Dame Sirith an atypical fabliau at best. ${ }^{23}$ If anything, it looks forward to later traditions of comic

\footnotetext{
${ }^{17}$ See Pleij, 'Literatuur als medicijn', p.30.

${ }^{18}$ George Staintsbury, The Flourishing Of Romance And The Rise Of Allegory, Periods of European Literature II (London: William Blackwood, 1897), p.282; Daron Burrows, The Stereotype of the Priest in the Old French Fabliaux: Anticlerical Satire and Lay Identity (Bern and New York: Peter Lang, 2005).

${ }^{19}$ John W. Baldwin, The Language of Sex: five voices from Northern France around 1200 (Chicago: University of Chicago Press, 1994), pp.252-5.

${ }^{20}$ Ivan Fonagy, Languages Within Language: an Evolutive Approach (Amsterdam: John Benjamins, 2001), p.335.

${ }^{21}$ Ben Parsons and Bas Jongenelen, 'A Play Of Three Suitors: A Neglected Middle Dutch Version of the "Entrapped Suitors" Story (ATU 1730)', Folklore 119 (2008), pp.62-74.

${ }^{22}$ Piero Boitani, English Medieval Narrative In the Thirteenth and Fourteenth Century (Cambridge: Cambridge University Press, 1982), p.29.

${ }^{23}$ Keith Busby, 'Dame Sirith and De Clerico et Puella', in Companion to Early Middle English Literature, ed. by N.H.G.E. Weldhoen and H. Aertsen (Amsterdam: Free Press, 1995), pp. 67-78.
} 
monologue in the Low Countries, such as the tafelspeel ('table play') or refereynen int zotte ('refrain of foolery'), as much as it looks back to the fabliau. ${ }^{24}$

This discrepancy also has implications for the text's criticism of the clergy. It is clear that De Frenesie's anticlericalism does not simply replicate the ecclesiastic satire of the fabliaux. As Alison Williams notes, in the fabliaux ridicule of the clergy generally assumes one particular form. It is dramatic, as the priest-figure is actively and aggressively punished by the events of the narrative: 'clergy...usually meet their downfall in one of two ways: threatened or actual castration; or violent death'. ${ }^{25} \mathrm{~A}$ particularly graphic instance of this is provided by the Prestre crucifié. In this story, a priest conceals himself from his mistress' husband, a sculptor, by hanging his naked body from a cross in the man's workshop: although the ruse is initially successful, the husband thinks the 'coilles' or balls excessive for a figure of Christ, and consequently hacks them off. ${ }^{26}$ As this example makes clear, corruption within the clergy is not addressed in general terms, or subject to moralisation or complaint by the text. Instead, it is treated as the localised transgression of a single churchman, who is savagely penalised at the conclusion of the story. ${ }^{27}$ Perhaps more importantly than this, the anticlerical satire of the fabliaux also possesses its own peculiar behavioural code. In the texts, the standards which form the basis of judgment and attack have a highly distinctive character. As Melissa Furrow notes, the principal crime that fabliau priests commit is a disruption of 'sexual allegiances'. ${ }^{28}$ From Du segretain moine, in which a monk is beaten to death while pursuing the wife of a merchant, to $D e$ Connebert, in which a priest's genitals are nailed to an anvil after his seduction of a blacksmith's wife, the clergy's lechery poses a threat to marriages, engagements and other relationships. ${ }^{29}$ It is this threat which the texts seek to castigate and defuse through their episodes of comic aggression. In short, the code which priests are accused of violating, in the name of which they are punished, is an emphatically secular one. ${ }^{30}$ At the centre of the texts is something resembling the popular 'morality' outlined by Carlo Ginzburg in his study of Italian anticlericalism: much like the 'precepts' Ginzburg identifies, fabliaux place great emphasis on 'human relationships' and 'duties to one's neighbour', allocating such issues far greater importance than any 'dogmatic or confessional considerations'. ${ }^{31}$ The satire of the

\footnotetext{
${ }^{24}$ See Dirk Coigneau, Refreinen in het zotte bij de rederijkers, 3 vols. (Ghent: Koninklijke Academie voor Nederlandse Taal- en Letterkunde, 1980-1983); Wim Hüsken, Noyt meerder vreucht-compositie en structuur van het komisch toneel in de Nederlanden voor de Renaissance (Deventer: Sub Rosa, 1987), pp.100-5; Veelderhande geneuchlijcke dichten, tafelspelen ende refereynen, ed. by E.J. Brill (Leiden: Brill, 1899); Herman Pleij, Van schelmen en schavuiten (Amsterdam: Querido, 1985); Een nyeuwe clucht boeck, ed. by Herman Pleij (Muiderburg: Dick Coutinho, 1983).

${ }_{25}$ Alison Williams, Tricksters and Pranksters: Roguery in French and German Literature of the Middle Ages and the Renaissance (Amsterdam: Editions Rodopi, 2000), p.51.

${ }^{26}$ The French Fabliau B.N. MS. 837, trans. and ed. by Raymond Eichman and John Duval, 2 vols. (New York: Garland, 1985), II, 62-67.

${ }^{27}$ On this point, see also R. Howard Bloch, The Scandal of the Fabliaux (Chicago: University of Chicago Press, 1986), pp.61-3.

${ }^{28}$ Melissa Furrow, 'Middle English Fabliaux and Modern Myth', English Literary History 56 (1989), p.13.

${ }^{29}$ Twelve Fabliaux: From MS F. Fr. 19152 of the Bibliothèque Nationale, ed. by T.B.W. Reid (Manchester: Manchester University Press, 1958), pp.34-6; Nouveau recueil de fabliaux et contes inédits des poètes français, ed. by M. Meon (Paris: Chez Chausseriau, 1823), pp.113-23.

${ }^{30}$ See Burrows, Stereotype of the Priest, p.121.

${ }^{31}$ Carlo Ginzburg, The Cheese and the Worms: the cosmos of a sixteenth-century miller, trans. by John and Anne Tedeschi (Baltimore: Johns Hopkins University Press, 1980), pp.39, 51.
} 
fabliaux is based in social and practical values, rather than spirituality or abstract virtue: as Larry Scanlon summarises, fabliau 'tend to be concerned with the politics of gender and class' rather than 'ecclesiology'. ${ }^{32}$ This means that they have little room for theological or doctrinal issues in their satire, since these are not part of the underlying code from which they draw. In Norris Lacy's phrase, the texts are 'antipriest but not really anticlerical', raising no religious or creedal objections. ${ }^{33}$ In sum, the fabliau's main instrument of satire is physical violence, and the principles it champions are lay and basically pragmatic.

De Frenesie does not follows this pattern in its own satire. Both the fabliau's characteristic method of executing satire, and the behavioural code at its centre, are absent from the text. There are no references to violence against the clergy, and the abuses it cites are trangressions of spiritual rather social ideals. For instance, in the poem's curious dream sequence the narrator describes a calf becoming a cardinal, and dealing in pardons. The creatures even owes its position to curial nepotism, being elevated purely because 'het was sire suster kint' ('it was the pope's sister's son'). Here the confusion of the human and animal, with its strong hint of sexual transgression on the part of the pope's 'suster', only strengthens the sense that the current conduct of the church is violating the true order of things. The poem then retains at its core a sense of propriety. It recognises a pattern for clerical conduct that ought to be upheld. This is quite at odds with the type of satire practised in the fabliau. Rather than disregarding all ecclesiastic ideals and allowing lay values absolute predominance, as Daron Burrows describes, there remains a sense that there is a correct standard for the church to follow. ${ }^{34}$ What is more, the way in which the satire is delivered differs from the rough-and-tumble of the fabliau's anticlericalism. The poem allows itself to pass direct comment on the abuses it cites, rather than drawing priests into episodes of vicious slapstick. Owing to these factors, it is perhaps more accurate to regard De Frenesie's usage of the fabliau as strategic. The fabliau is being used as little more than a stem on to which other satirical elements may be grafted. No doubt the author has chosen it as one which is conducive to these sentiments, which possesses a generalised hostility towards the church, but he is not governed by its form. The text is employing the fabliau simply as a basic stem, or a frame in which other material can be arranged. In terms of its anticlericalism, the poem uses the fabliau only for its loose 'anti-priest' sensibility, rather than for its specific tactics or outlook.

This can be seen clearly in the main body of the poem. Here the characteristic idioms of several different forms of satire are used extensively. One of the clearest instances of this occurs in poem's attack on 'symonien', or 'simony'. Complaining that he is likely to be cheated out of his stipend once he has secured it, the narrator remarks:

Soe leecht ment in de vouden

dat ic en behoude niet...

Ende constu spreken geen latijn?

Ay here, een florijn

es daer beter, geloeft mi des,

\footnotetext{
${ }^{32}$ Larry Scanlon, Narrative, Authority and Power: the medieval exemplum and the Chaucerian tradition (Cambridge: Cambridge University Press, 1994), p.163.

${ }^{33}$ Norris J. Lacy, Reading Fabliaux (New York: Garland, 1993), p.xviii.

${ }^{34}$ Burrows, Stereotype of the Priest, p.121.
} 
dan een sac vol latijns es.

(They'll twist my case back-to-front

So that I must walk away poor...

Well, don't you understand Latin?

Aye, I do, my lord, a florin

Is much better, believe you this,

Than a sack full of Latin is.)

This brief sequence contains numerous echoes of Lain venality satire which, according to John Yunck, received its greatest impetus from the expansion of the papal chancery in the twelfth and thirteenth centuries. ${ }^{35}$ For instance, the final reflection that money is superior to Latin makes use of a device which occurs with great frequency throughout the Latin satires. Such ironic comparisons are often created: the earlier poets speak of 'lucrum Lucam superat, Marco marcam praeponderat'('lucre overcoming Luke, the mark outweighing Mark') and 'crucis denarii mira potentia' ('the miraculous power of the cross of the coin'). ${ }^{36}$ Mock masses and gospels dramatise this conceit, as their parody literally 'substitutes money for God'. ${ }^{37}$ As Alexander Murray writes, the satires routinely claim that 'money could do miracles... what official doctrine predicated of God, Father, Son, and Holy Ghost, was in real life observably true of money, ${ }^{38}$ In issuing a comparable statement regarding a key attribute of the clergy, the Dutch poet situates himself in the same position, similarly hinting at 'money's appropriation of miracle and sacrament'. Further hints of goliardic money-satire appear in the narrator's suspicion that his case will be 'twisted back-to-front' or 'contorted'. The phrase used here recalls the commonplace that money has the ability to invert and distort, to 'bring about the fraternization of incompatibles', as Marx states of a sixteenth-century example of the tradition. ${ }^{40}$ The opening lines of one piece show this convention clearly: 'manus ferens munera/ pium facit impium...nummus lenit aspera' ('the hand bearing bribes makes the scandalous holy...the coin smoothes over sharpness'). ${ }^{41}$ The suspicions of De Frenesie's narrator at least resemble the twisting action attributed to money, the reversal of 'proper relations', and conversion of 'values' into their opposites. ${ }^{42}$

Perhaps even more significantly, the general legal framework in which such complaints are usually framed is also maintained by the poem. This template seems to

\footnotetext{
${ }^{35}$ John Yunck, The Lineage of Lady Meed: The Development of Mediaeval Venality Satire (Notre Dame: University of Notre Dame Press, 1963), p.85.

36 'Song on the Bishops', in The Political Songs of England: From the Reign of John to that of Edward II, ed. by Thomas Wright (London: Camden Society, 1839), p.11; 'De Cruce Denarii', in Latin Poems Commonly Attributed to Walter Mapes, ed. by Thomas Wright (London: Camden Society, 1841), p.223.

${ }^{37}$ Martha Bayless, Parody in the Middle Ages: the Latin tradition (Ann Arbor: University of Michigan Press, 1996), p.201.

${ }^{38}$ Alexander Murray, Reason and Society in the Middle Ages (Oxford: Clarendon Press, 1978), p.76.

${ }^{39}$ Nicholas G. Round, 'Juan Ruiz and Some Versions of Nummus', in The Medieval Mind: Hispanic Studies in Honour of Alan Deyermond, ed. by Ian Macpherson and Ralph Penny (London: Tamesis, 1999), p.393.

${ }^{40}$ Karl Marx, Early Writings, trans. and ed. by T.B. Bottomore (New York: McGraw-Hill, 1964), p.192.

41 'De Nummo', in Latin Poems Attributed to Walter Mapes, p.226.

42 Andrew Cowell, At Play in the Tavern: Signs, Coins, and Bodies in the Middle Ages (Ann Arbor: University of Michigan Press, 1999), p.88.
} 
have been fixed by Bernard of Clairvaux's influential treatise De consideratione (c.1148), which warns against 'advocatos et procuratores, qui ex iniquitate quaestum faciunt' ('advocates and prosecutors who make profit out of evil'), describing such figures as 'sectatores lucrorum' ('followers of profit') who 'abscondant aes suum a te' ('conceal their wealth from you'). ${ }^{43}$ Several later pieces follow Bernard's lead, also identifying the law as the arena in which money's power is most keenly felt. For instance, Walter of Chatillon states that 'nummus cunctis imperat/ Reos solvit, iustos ligat, impedit et liberat' ('the coin commands all, frees plaintiffs, binds the just, captures and sets free'), while an anonoymous contemporary registers a similar complaint: 'Nummus ubi loquitur/ fit juris confusio' ('where the coin speaks it makes a muddle of the law'). ${ }^{44}$ The ease with which De Frenesie drifts between the lawcourts, simony and money stems from this tradition of Latin satire, and the links already established there.

The next important set of borrowings in the poem stem from a tradition which Kathryn Kerby-Fulton defines as 'reformist apocalypticism'. This grouping encompasses such texts as the Scivias of Hildegaard of Bingen (c.1151), Joachim of Fiore's Expositio in Apocalipsim (c.1184), and Bridget of Sweden's Tractatus de summis pontificibus (c.1370). Broadly speaking, this literature is characterised by its use of prophecy as a means of reddressing contemporary abuses and irregularities. As Kerby-Fulton defines it: 'the state of the Church's religious orders or of one particular order or heretical group is nearly always at the heart of the apocalypticist's concern...they handed down judgments on contemporaries, envisioned Church reform by brute force, and reacted indignantly to current political, social, and religious events...the apocalyptic crisis you will suffer, they warn the reader, is selfinstigated'. ${ }^{45}$ In short, the mode forecasts a particular future in order to upbraid the present. It uses visionary language and imagery not to emphasise the power of divine intervention or the obscurities of providence, but to insist on a clear continuity between the present and the future it envisions: this in turn allows it to criticise, condemn or ridicule the church as it currently conducts itself. Its central tactic is to apply 'the characteristics that were expected to occur at the end of history to reform of the church'. ${ }^{46}$

In its borrowing from this tradition, De Frenesie mimics the general tone and timbre of apocalyptic works. The relevant section of the poem occurs after a brief conversation between the prostitute character and the narrator. Following this interchange, the narrator breaks off to describe a dream he has had. He claims to have seen 'een calf singen messe' ('a calf singing Mass') which later becomes a cardinal at Rome, where it has a lucrative career 'vercochte om gelt pardoen', or 'hawking pardons'. This is followed by a vision of a priest in Kempen, who remains strangely indifferent as a child he is baptising is transformed into a goat in his hands: 'hine

\footnotetext{
${ }^{43}$ Bernard of Clairvaux, De Consideratione libri quinque ad Eugenium tertium, I.xi, in Sancti Bernard Opera, ed. by Jean Leclercq, C.H. Talbot and Henri Rochais, 8 vols. (Romae: Editiones Cistercienses, 1957-1977) III, 410.

${ }^{44}$ Walter of Chatillon, Moralische-Satirische Gedichte, ed. by Karl Strecker (Heidelberg: Bibliothek der klassischen Altertumswissenschaften, 1929), p.110; 'De Nummo', p.227.

45 Kathryn Kerby-Fulton, Reformist Apocalypticism and Piers Plowman, Cambridge Studies in Medieval Literature 7 (Cambridge and New York: Cambridge University Press, 1990), pp.4-5.

46 E. Randolph David, 'Abbot Joachim of Fiore: a reformist apocalyptic', in Fearful Hope: Approaching the New Millennium, ed. by Christopher Kleinhenz and Fannie LeMoine (Madison: Wisconsin University Press, 1999), p.207.
} 
gauer niet omme enen dreet/ dattie dinc bet vore' ('he cared not a fart/ thinking all he'd though before'). Aside from the fact that this sequence occurs within the visionary framework of a 'drome', other details link it to prophetic literature. Much of the material here contains clear biblical resonances. The lucrative calf that proves 'den paeus willecome' ('to the pope most welcome') not only suggests the idol of Exodus 32.4-35, which leads the Israelites into a 'heinous sin' to be paid for 'in the day of revenge', it also alludes to similar creatures in the prophetic books. ${ }^{47}$ But this episode finds perhaps its most significant echo in the teleology of the Pauline epistles. The coincidence of the goat and calf in the poem recalls Paul's description of Christ's sacrifice, and of the future salvation the Passion secured: 'but Christ, being come an high Priest of the good things to come...neither by the blood of goats or of calves, but by his own blood, entered once into the Holies'. ${ }^{48}$ The fact that the narrator has witnessed what Paul specifically rules out adds to the sense of catastrophe, as 'things' in the vision drift badly away from the 'good' promised here. Not only does this align the text with biblical prophecy, it also connects it with the apocalyptic texts KerbyFulton describes, as such use of scripture is entirely consistent with this tradition, and its concerted efforts 'to fit the present time and coming periods of time into a preeschatological pattern'. 49

The manner in which the poem shapes its anticlerical satire is also in line with apocalyptic writing. In design this section resembles the most overtly critical of such texts. Some striking parallels emerge if it is compared with William of St Amour's De periculis novissimorum temporum (1256), the text which initiated a fruitful tradition of antifraternal polemic and satire. ${ }^{50}$ In this work, William listed a series of thirty-nine 'signa' by which the 'pseudo-praedicatores' or 'false apostles' of the Antichrist will makes themselves known, drawing together material from the Pauline epistles to make his charges. The substance of the accusations themselves clearly points to the behaviour of the friars, even if this is never openly stated: his false apostles are 'penetrantes domos' ('stealers into homes') and 'girovagi' ('aimless wanderers'). ${ }^{51}$ In much the same way the author of De Frenesie marries together caricatures of the clergy with a vision of grotesque cosmic upheaval. The role allocated to the church in this turmoil is also similar in both texts. De Frenesie implicates the church in the collapse of the existing order, not in the new order that will presumably emerge from it. Just as William's 'lupi graves' ('ravening wolves') are catalysts of Armageddon, heralding the arrival of Antichrist, De Frenesie's clerics also side with chaos. The pope directly colludes and profits from the singing calf, raising it to the level of cardinal and growing wealthy from the indulgences it peddles, whereas the brainless Kempen priest is simply unable to recognise the disintegration at his fingertips, and consequently just as unlikely to challenge it.

However, despite these echoes, it is also interesting to note that the author adapts his sources in subtle but pivotal ways. The poet was not a slavish follower of the Latin

\footnotetext{
${ }^{47}$ See for instance Hosea 14.2, Malachi 4.2, and Apocalypse 4.7.

${ }^{48}$ Hebrews 9.11-12 (Douay-Rheims translation).

${ }^{49}$ Kathryn Kerby-Fulton, Reformist Apocalypticism, p.9.

${ }^{50}$ See Arnold Williams, 'Chaucer and the Friars', Speculum 28 (1953), pp.499-513; Penn R. Szittya, 'The Antifraternal Tradition in Middle English', Speculum 52 (1977), pp.287-315; Penn R. Szittya, The Antifraternal Tradition in Medieval Literature (Princeton: Princeton University Press, 1986). KerbyFulton discusses De periculis in Reformist Apocalypticism, pp.133-61

${ }^{51}$ William of Saint-Amour, De periculis novissimorum temporum: a critical edition, ed. by Guy Geltner, Dallas Medieval Texts 8 (Paris: Peeters, 2008).
} 
traditions. He had no hesitation modifying the themes he inherited, often in ways that directly contradict the central thrust of such material. For instance, his deployment of venality satire forces a new shape on to the convention. Although De Frenesie's accusations are drawn from money-satire, it is a curious fact that money itself receives scant mention: only at the end of this embedded episode does the poem refer to any form of cash at all, in the form of 'a florin'. Instead, the poem's attention is fixed on simony and the anticipated trial itself. In other words, it is less interested in money and more inclined towards the actions that money facilitates and influences. This represents a fairly radical break with the Latin poems from which the Dutch writer has drawn. It is more common for money satires to present money as an absolutely independent agent, which directs and commands all other beings. In fact, to literalise its agency, it is often converted into such authoritative personifications as Dan Denier, Regina Pecunia, Nummus or Dominus Denarius. ${ }^{52}$ De Frenesie effectively repersonalises this form of satire, tacitly rejecting the notion that money is an actor in its own right, a determinant of human action. By dissolving the fiction prevalent in the Latin satire, it succeeds in reasserting human resposibility for the effects of money. It is concerned with performers of sin, rather than its object. It refuses to let corruption be separated from specifically human actors and be regarded as an agency in itself, even in ironic play.

Similar changes are evident in the poem's treatment of apocalyptic complaint. Here the text forces the tradition to undergo revisions that are no less critical. Just as produces a money satire which does not focus on money, in the same way it issues a vision which is not in fact prophetic. Although couched in the language of prophecy, even grounding itself in passages of scripture, the narrator's dream sheds any pretence of forecasting the future. When the narrator recounts his dream, he gives no impression that the events he has seen are about to happen: the entire episode is phrased as though it was directly witnessed by the dreamer. He has no expectation that his vision will eventually come to fruition, but treats it as though it occurred as he dreamt it. The poem thus dispenses with the usual rhetoricl stance of this form of protest. Although Kerby-Fulton's apocalyptic writers are also concerned primarily with the here and now in their fictions, De Frenesie avoids the customary circumlocutions they assume. It does not shift its focus from the contemporary by mediating its critique through a projected future, but keeps its gaze trained on the current. The poet again strips away a device habitually deployed by the tradition he inherits, much as he does when making use of venality satire.

There is also a third alteration at work in the poem, which is perhaps the most important that the author introduces. This is simply the fact that various forms of anticlerical satire are collected in a single work. The assemblage of material from the fabliau, the venality satire and apocalyptic complaint also marks a level of innovation on the part of the author. Unlike the texts which De Frenesie imitates, the poem is not approaching the genres of medieval satire as self-enclosed frameworks, which are to be inhabited to the exclusion of one another. Instead it takes a broader view, seeing them not as discrete forms, but as a range of devices which are combinable into a single attack.

\footnotetext{
${ }^{52}$ See Latin Poems Attributed to Walter Mapes, pp.355-9; John A. Yunck, 'Dan Denarius: the Almighty Penny and the Fifteenth Century Poets', American Journal of Economics and Sociology 20 (1961), pp.207-22.
} 
This is not to say that the poet is completely successful in deploying the various elements he draws on. There is a clear tension at work in De Frenesie between the different forms of satire it contains. Especially problematic is his dependence on the fabliau persona of the lecherous and lazy student. Using this mouthpiece presumably serves to legitimate the poem's attacks, as it exploits the dispensation conventionally awarded to foolish speakers: much the same device would be used two centuries later by Erasmus, another Netherlandic sairist, in his Moriae Encomium. Nonetheless, in the case of De Frenesie the student persona impedes as much as it liberates, depriving some assertions of their full force. This becomes most conspicuous during the prostitute's interjection into his speech. It is at this point that the only explicit moralisation in the poem occurs. The girl issues the proverbial statement 'Ki bien fra bien ara' or 'who does good will receive good'. The narrator is not equipped to understand this simple moral precept. All he knows is 'hets walsch dat gi spreect' ('it is French you have spoken'), and begins to complain that the prostitute has disturbed his sleep with her 'clapt' or 'clattering'. On the one hand, this is a clear joke at the narrator's expense, which extends the general anticlerical thrust of the poem. The point seems to be that his learning and his residence in France, which is supposed to install him into the church as an intermediary between layman and God, has left him unable to decode even a plain statement of how virtue is to be attained. However, this moment also serves mark the limits of his power as a satiric persona. It is interesting to note that his inability to understand the prostitute's French is not consistent with his performance elsewhere. At other points in the poem he boasts of his fluency with French culture and language, as he bets 'cinq contre six' at the dice-table, and knows how to cook with garlic. This inconsistency calls attention to the contradictory role that De Frenesie forces him to play. On the one hand, he is a preacher, a revealer of moral truths, attacking the papacy for its emptiness, and the prevalence of simony in the church; on the other he is an amoral cler escolier, with his provenance in the fabliaux, incapable of comprehending direct moral pronouncements. Just as his French suddenly fails him when he encounters a piece of direct exhortation, his ability to use the language of satire is only partial: it founders before the ethical implications of its arguments. The full meaning of his attacks on the papacy and simony are not only never spelled out, but never can be, owing to constraints imposed by their speaker. The poem's foundation in the fabliau results in a figure that can not claim the moral sanction that his forceful denunciations demand. What remains therefore is an uneasy tension between vigorous attack and playful irony. The collage of different strands of satire generates friction in the text, as the forms of text carry differing levels of gravity in their propositions.

Nonetheless, the very fact that De Frenesie makes an attempt to coordinate disparate material in a single text is revealing. This manoeuvre suggests that the text is trying to articulate a new position or set of concerns, one which is not currently addressed by existing satiric discourse. The ease with which it moves between different traditions, and the freedom with which it incorporates material from each one, suggests that it has no strong affinity with any one of them. It is able to bring these forms of satire together because it is outside the scope of any one of them, viewing each one from a point beyond its its framwork and priorities. This means that it is not pinned to their particular set of interests, or entirely governed by their concerns. The types of Latin satire that occur within De Frenesie are united by their basis in specific outlooks, particular conflicts, and definite partisan objectives. Most forms of medieval anticlerical satire arose out of larger disputes or feuds, almost invariably ones 
involving one order within the church against another: in John Van Engen's overview, 'whenever a religious movement attained an institutional status surpassing and threatening the privileges of others [...] satire commonly sprang up... so it was with Cluny...then with the Roman curia as it centralised law...then with the Cistercians as their economic power built up...then with the mendicant friars'. ${ }^{53}$ The Latin forms that De Frenesie calls on are no exception to this rule. Venality satire seems to owe its existence to the Investiture Controversy, while the satiric vein of apocalypticism probably arose out of the mendicant and secular conflicts at Paris in the $1250 \mathrm{~s} .{ }^{54} \mathrm{In}$ other words, the satiric forms that De Frenesie inherits took shape in definite tensions, taking aim against specific targets for specific ends. As a result of this, they have predetermined sympathies, as they are intended to defend against an opponent as much as to attack a target. Each one is designed to impute a set of charges against a particular group, while championing the order or party which issued it.

The fact that De Frenesie is able to to gather several of these types of Latin satire into a broader, more miscellaneous attack suggests that it is informed by quite different sympathies. It does not have to remain within the generic contours of any particular tradition since it has no affinities to any of the priorities they express. It may call on all of them freely because it stands outside all equally. This in turn reveals something about the position in which the poem is situated: a position which, in some respects, resembles the 'new anticlericalism' Wendy Scase identifies in late fourteenth-century English poetry. ${ }^{55}$ The fact that the poem's attacks are far-reaching and contain no endorsement of any particular group firmly suggests that the poem is issued from, or at least manages to draw on or otherwise register, a lay standpoint. Its ability to see the chuch as a single structure, not a collection of contending positions, may be the result of its being issued from outside the priesthood. It can treat the clergy as a single broad target since it is not limited by any allegiances, or anchored to any point within the church.

Its other modifications are certainly consistent with this stance. The poem's revisions of Latin satirical forms bear witness to similar commitments. Its treatment of venality satire in particular seems to evoke lay sensibilities and values, especially in its refusal to make money the direct target of complaint. By moving its attention away from money as a supposed actor, and towards the actions it facilitates, De Frenesie emphatically makes the church the focus of its attacks. The poem refuses to escape into the fantastic belief that money itself is an autonomous director of sin, and instead stresses the role of the priesthood themselves as the perpetrators of corruption. The poem is therefore not interested in localising ecclesiastic greed, in pinning it down to an abstract cause within the church: instead it implicates the church itself as a whole in its attacks. It is, once again, taking a broader view, disregarding details and subtleties in favour of attacking the church more even-handedly and comprehensively. Again, the form of satire that De Frenesie deploys seems to display marked

\footnotetext{
${ }^{53}$ John Van Engen, 'Late Medieval Anticlericalism: the case of the new devout', in Anticlericalism in Late Medieval and Early Modern Europe, ed. by Peter A. Dykema and Heiko A. Oberman, Studies in Medieval and Reformation Thought, 51 (Leiden, New York and Koln: E.J. Brill, 1993), pp.19-20.

${ }^{54}$ Pascale Bourgain, 'The Image in Rome in Literature: Anti-Roman Satire', in The papacy: an encyclopedia, ed. by Philippe Levillain and John W. O’Malley (London: Routledge, 2002), p.750; Williams, 'Chaucer and the Friars', p.501.

${ }^{55}$ See Wendy Scase, Piers Plowman and the New Anticlericalism (Cambridge: Cambridge University Press, 1989); Wendy Scase, 'Satire', in Medieval England: an encyclopedia, ed. by Paul E. Szarmach and others (New York and London: Garland Publishing, 1998), pp.665-7.
} 
sympathies with the laity. It addresses the clergy from outside its parameters, coalescing it into a single group, rather than concentrating on only one limited point. The position its author is writing in appears to have its roots in the laity, as he uses this situation as the basis of his satire.

The poem's alterations of the prophetic tradition follow much the same course. Removing any teleological elements from the vision-section produces a comparable effect. This change shifts emphasis away from events that will supposedly affect or befall the church. Usually the satire of apocalyptic literature relies on its predictive intention, as it promises some future recompense for its chosen target: hence Bridget of Sweden foresees that judges 'will fry in the hottest pan', while Langland vows that 'pe abbot of engelond and the abbesse his nese/ Shal haue a knok on vppon here crounes' ${ }^{56}$ Disregarding the future is therefore tantamount to ignoring the destiny of the clergy, the penalties it stands to undergo. This means that by moving from the future to the present, the poem is concentrating not on the church as the object of some forthcoming action, but as a subject in itself. It focuses on the priesthood as a performer rather than a prosepective victim: it is not concerned with what happens to the church later, but with what the church does in the here and now. The fact that the poet sees the church in such strictly active terms suggests that he regards it as a body with specific functions to perform. This in turn implies that the church is principally a pastoral or ministerial structure for the poem, an institution which carries out rituals, services and counsel, which works for the benefit of its public. De Frenesie again seems to stand with the laity, conceiving the church in terms of its outward role, not its own identity or fortune. Its lack of interest in the church's own experience, either in the present or future, therefore leads to the same conclusion as other features in the poem. De Frenesie has no regard for such issues because it stands outside of the ecclesiastic structure.

In sum, the manner in which De Frenesie uses its satire suggest a basic affinity with the laity. The fact that it is free to draw on several different forms of satire places it outside the priesthood, while the revisions it introduces inject distinctly secular concerns into the material it borrows. What De Frenesie therefore represents is the emergence of a sense of moral authority within the laity, one which is sufficiently well-established to confront the church directly, and broach subjects that had previously been confined to clerical discourse alone. Even if the poem is not entirely secure in exercising this authority, cloaking its assertions in self-effacing play and ribaldry, it is at least sufficiently certain of itself to deploy complaint in a vernacular text. At the very least, it shows a clear willingness to critique and lampoon contemporary abuses, and even modify them to address more specific concerns.

This lay confidence is something of a new development in satire. While the fabliaux had been able to criticise the priesthood while drawing on recognisably lay values, this was at the expense of doctrinal or ecclesiological engagement: as V.A. Kolve states, the 'fabliau system' has no room for 'transcendental meaning and spiritual destinities', since the form is governed by practicality and 'respect for ordinary

\footnotetext{
${ }^{56}$ The Revelations of St. Birgitta of Sweden, trans. and ed. by Denis Searby and Bridget Morris, 2 vols. (Oxford: Oxford University Press, 2006), I.156; William Langland, Piers Plowman: the C version, ed. by George Russell and George Kane (London: Athlone Press, 1997), p.92.
} 
limits'. ${ }^{57}$ De Frenesie on the other hand comfortably directs its attention towards moral and ethical issues, even if it does not entirely transcend the remits of fabliau. There is underlying the poem, then, a sense that the laity do have a religious awareness that may be legitimately voiced, that commentary on such matters is not the exclusive province of the priesthood itself. That this position should have become available in the Low Countries at the beginning of the fourteenth century should not surprise. After all, popular religious movements had proliferated in the area since the late twelfth century, most notably the beghards, the beguines, and the urban fraternities that would later develop into the Chambers of Rhetoric. ${ }^{58}$ The laity of the region were therefore relatively well-educated and informed, having sufficient knowledge of religious affairs to involve themselves in them. In fact by the time that De Frenesie was written Flanders had already produced one vernacular author who showed a similar willingness to criticise the church: Jacob van Maerlant's Van den Lande van Oversee (c.1291) angrily denounces a range of contemporary abuses in its reflections on the loss of Acre. ${ }^{59}$ It is this background of growing lay subjectivity that the poem channels and reflects, as the ideas it uses in its attacks are made possible by such conditions. Consequently, De Frenesie should be regarded first and foremost as an important step in the progression of anticlerical satire in the Netherlands, rather than an isolated text or a mere reprisal of fabliau forms. It is an important witness to the emergence of a lay religious awareness, and of critical sensibility within this, as this is the key resource for its satire. Although its persona stands on the margins of the priesthood, in minor orders seeking a benefice, the poem's position outside the church is more important than the narrator's desired entry into it.

\footnotetext{
${ }^{57}$ V.A. Kolve, Chaucer and the Imagery of Narrative: The First Five Canterbury Tales (Stanford: Stanford University Press, 1984), p.214.

${ }^{58}$ Wim Husken, 'Civic Patronage in Early Fifteenth-Century Religious Drama in the Low Countries', in Civic Ritual and Drama, ed. by Alexandra F. Johnston and Wim N. M. Husken (Amsterdam: Rodopi, 1997), pp.107-23; Walter Simons, Cities of Ladies: Beguine Communities in the Medieval Low Countries, 1200-1565 (Philadelphia: University of Pennsylvania Press, 2003); Andrew Pettegree, Reformation And The Culture Of Persuasion (Cambridge: Cambridge University Press, 2005); Herman Pleij, 'The Rise of Urban Literature in the Low Countries', in in Medieval Dutch Literature in its European Context, ed. by Erik Kooper (Cambridge: Cambridge University Press, 2006), pp.62-80.

${ }^{59}$ Jacob van Maerlant, Van den lande van ouer zee, ed. by Garmt Stuiveling (Amsterdam: z.j. 1967).
} 


\section{Appendix: Dit es de Frenesie}

From Cornelis Kruyskamp, De middelnederlandse boerden voor het eerst verzameld ('s-Gravenhage: M. Nijhoff, 1957), p. 96-99

Het dich[t] al dat lepel lect: waendi dat ic bem vergect, dat ic oec niet dichte ende make, des nacht als ic niet en vake?

5 menichgen, als hi slaept, sijn ers herde wide gaept ende blaest als ene bosine.

Ay ute vercorne fine! des es leden menichgen dach,

10 dat mi v minne int herte lach, ende gine wilt mijns niet ontfarmen. Dicken hebbedi doen verwarmen mijn herte ende gemaect cout; om v bem ic worden out

15 ende graeu als ene catte, ende gine achtes dit no datte. ocht v minne mi steruen daede, wie soude mi betren die scaede? Lachtijs, maecti v sceren,

20 So willics mi af keren, want hine dult algader niet die te haluen wege weder tiet; anders waric in dole.

Nv liggic te parijs ter scole

25 ende bem daer een studant. Selden coemt mi boec in die hant, maer ic lere ontginnen pasteiden; bem ic dan ter quader weiden, es een quaet dorp dan parijs?

30 ic wedde sinc contre sijs, nochtan eysch ic toe twee aes: die seide dat ic ware .i. dwaes, hine ware mi niet willecome. Alsic dan weder thus come,

35 so bem ic meester vander arten ende wille eten vleesch ende tarten ende hebbe gewonden den croec. Ic soude node stoeten een loec, maer ic songe wel een montet.

40 Int leste hebbic an een net ende bem een everardijn. Ic dronke gerne goeden wijn, maer ic en weet waermet copen, dus moet ic achter lande lopen

45 te minen moyen, te minen maegen, die mijn ongheual luttel claegen. 
so hebbic die prouende met ghewelde tusscen couden berge ende biestervelde; so coemt een ander ende wilse mi nemen:

50 gaet ten biscop van bremen, hi sal v te rechte houden.

Soe leecht ment in de vouden dat ic en behoude niet.

Dus es den menichgen gesciet

55 die sonder recht tsine verloes, want dat paepscap es al loes.

Ende constu spreken geen latijn?

Ay here, een florijn

es daer beter, geloeft mi des,

60 dan een sac vol latijns es; dit coemt al bi symonien.

Nv willic scone vrouwen vrien ende moet gelt costen mede al $[\ldots]$

65 mi bliv[...]

die duuel soude mi bet hebben

want ic bem al sonder goet

ende ligge onder voet

Ki bien fra bien ara.

70 Waendi dat ic niet en versta?

Hets walsch dat gi spreect.

Gi hebt mi vten slape gewect, wel leede moete $\mathrm{v}$ gescien! Ic hebbe in minen drome gesien

75 een calf singen messe en kende lettren niet sesse, ende het wert cardinael te rome ende was den paeus willecome, want het was sire suster kint -

80 dus es die werelt nv gescint het vercochte om gelt pardoen Ic sach een kint kerstin doen van enen pape in kempin lande, ende onder des papen hande

85 so wort dat kint een geet. hine gauer niet omme enen dreet dattie dinc bet vore.

Wat wijt mi dese hoere?

Si clapt mijn hoeft ontwee!

90 deus, mi es herde wee! ende legt mi ouer dander side. Mi dunct altenen dat ic ride alse nv langes, alse nv dwers, op eens graeus moencs ers. 


\section{This Is The Madness: a verse translation}

Rhyming is like eating with a spoon:

Do you think that I'm a buffoon,

That I do not rhyme, or poems make

During the night, if I'm awake?

5 Many people, while they are sleeping,

Still have their arses widely gaping

And blasting away like a bugel.

Ah, my chosen one, finest jewel!

There has been, alas, many a day

10 When love for you in my heart lay,

But you refused when I entreated.

Several times you have heated

My poor heart, then made it cold;

Because of you I have grown old

15 And I am as grey as a cat,

But you don't give a this or that.

If my love would kill me dead,

Who would see my pain repaid?

Laughing, you will mock my heart,

20 Because of this I shall depart,

It is not foolish in any way

If one turns back after halfway;

If I did not, I'd be a fool.

Now I lie in Paris at school

25 For I'm a student in that land.

A book rarely comes near my hand,

More about cutting pies I learn;

Have I taken a wrong turn,

Is this the wrong place, Paris?

30 At the dice I bet cinq contre six,

Holding two aces in reserve:

Call me a fool, if you have the nerve

But my welcome you'll never know.

When back to my home I go,

35 I will be a master of arts

And I will dine on meat and tarts

And in curls I'll wear my hair.

Garlic dishes I'll prepare,

And I will sing a proper motet.

40 At the worst I'll wear a net

And become a mendicant friar.

I drank good wine in times prior,

But no-one now buys drinks for me,

So through all lands I'll wander free

45 To my aunts and relatives,

I complain how little fortune gives.

I'll wield my prebend, keen and bold,

Between Wasteland and Mount Cold; 
If anyone tries to take it away,

50 Bremen's bishop he must sway,

Who gives whatever verdict you want.

They'll twist my case back-to-front

So that I must walk away poor.

It's happened to many men before.

55 They found they'd lost everything,

For the papacy contains nothing.

Well, don't you understand Latin?

Aye, I do, my lord, a florin

Is much better, believe you this,

60 Than a sack full of Latin is;

From simony all this grew.

Now I want a sweet girl to screw

And that will cost me money

All $[\ldots]$

65 It stays $[\ldots]$

The devil has a tight grip on me

Because fine goods I wholly lack,

I lie at the bottom of the stack.

Qui bien fera bien ira.

70 You think I don't hear? You're in error.

I know it's French you have spoken.

And my sleep you have now broken,

You'll be sorry, of that be sure!

In my dream I clearly saw

75 A calf sing the Eucharist

It could not read, or get the gist,

It became a cardinal in Rome

And to the pope was most welcome,

Because it was his sister's son -

80 This world is a shameful one -

It hawked pardons in my vision.

I next saw a child's baptism

By a priest in the Kempen lands,

And right there in the priest's hands

85 Into a goat the poor child turned.

The priest cared not a fart, unconcerned

He just thought all he'd thought before.

What is she prattling now, this whore?

She splits my head with her nonsense!

90 Deus, the pain is most intense!

She lies over on my other side.

I think she means that I should ride

First one way, and then the other,

Up the arse of a Franciscan brother. 